\title{
Caspase-3-like activity and proteasome degradation in grapevine suspension cell cultures undergoing silver-induced programmed cell death
}

\author{
Antonio Filippi, Marco Zancani, Elisa Petrussa, Enrico Braidot*
}

\section{A R T I C L E I N F O}

\section{Keywords:}

Caspase-like proteins

Programmed cell death

Proteasome

Reactive oxygen species

Silver metal

Vitis vinifera

\begin{abstract}
A B S T R A C T
Toxic metal contamination is one of the major environmental concerns of the recent decade, due to the large application of metals in industrial, healthcare and commercial products, even in the form of nanostructures and nanomaterials. Nevertheless, the effects of silver $\left(\mathrm{Ag}^{+}\right)$on plants have not yet thoroughly elucidated. Therefore, suspension cell cultures of grapevine were used as a model for investigating silver toxicity. To do this, oxidative stress and programmed cell death (PCD), evaluated as reactive oxygen species production, caspase-3-like activity and ubiquitin-proteasome system, were investigated.

As a result, the highest concentration $(10 \mu \mathrm{M})$ of $\mathrm{Ag}^{+}$caused a rapid (within $24 \mathrm{~h}$ ) induction of PCD (approx. $80 \%$ ), accompanied by generation of reactive oxygen species and activation of caspase-3-like activity. In the presence of specific inhibitor of this enzyme, a partial recovery of cell viability and a strong inhibition of caspase-3-like activity was observed. In addition, silver-induced PCD was accompanied either by increase of poly-ubiquitin conjugated proteins and degradation of subunit PBA1 of the proteasome $20 \mathrm{~S}$ core, similarly to what found for metal-induced neurotoxicity in animals.

The present study shows that silver could induce PCD in grapevine suspension cell cultures, mediated by caspase-3-like activity and oxidative stress. These effects were associated to accumulation of poly-ubiquitin conjugated proteins, suggesting the impairment of ubiquitin-proteasome complex, confirmed by the decrease of the PBA1 subunit. These findings indicate that animal and plant cells could share a common pathway in response to toxic metal, which involves PCD and disassembling of proteasome complex.
\end{abstract}

\section{Introduction}

Programmed cell death (PCD) is an integral part of multicellular organism's life cycle. This process is induced by various stimuli (developmental and environmental cues), involving the expression of different genes in specific sub-cellular compartments (endoplasmic reticulum, plasma membrane, vacuole, mitochondrion and chloroplast) (Cai et al., 2014; Li et al., 2010; Üstün et al., 2016). Plants exploit PCD during different developmental processes, such as senescence, embryogenesis, development of vascular tissues and sex determination in unisexual plants (Van Aken and Van
Breusegem, 2015; Xu et al., 2005). PCD represents also a key mechanism in plant-pathogen interaction, because it can be locally elicited where the tissue is invaded, reducing the growth of the pathogen (Jiao et al., 2014; Kim et al., 2003).

It is well known that multiple forms of PCD exist in both plants and animals, sharing a number of similar hallmarks, such as DNA fragmentation and cell shrinkage (Kim et al., 2003; Vartapetian et al., 2011; Zancani et al., 2015).

Many observations suggest that oxidative stress and generation of reactive oxygen species (ROS) may be an early event of plant response to several biotic and abiotic stresses, leading to PCD (Huang et al., 2014). The cellular sites of the most important meta-

Abbreviations: U, arbitrary units; Ac-DEVD-pNA, $N$-acetyl-Asp-Glu-Val-Asp-p-nitroanilide; DEVD-CHO, Asp-Glu-Val-Asp-aldehyde; DTE, 1,4-dithioerythritol; FDA, fluorescein diacetate;


PBA1, proteasome beta A1 subunit; ROS, reactive oxygen species; 20SP, 20S proteasome; Ub, ubiquitin; UPS, ubiquitin-proteasome system.

* Corresponding author at: Dept. of Agricultural, Food, Environmental and Animal Sciences (Di4A), University of Udine, Via delle Scienze 91, 33100 Udine, Italy.

Email address: enrico.braidot@uniud.it (E. Braidot) 
bolic processes, such as chloroplasts and mitochondria, are also the major ROS producers and may generate intermediate signals involved in PCD (Borutaite and Brown, 2001; Li and Xing, 2011; Van Breusegem and Dat, 2006).

A general feature of PCD is the triggering of key enzymes, such as caspases, a family of cysteine-proteases, occurring as proenzymes in most animal cells (Fuentes-Prior and Salvesen, 2004; Kumar, 2007) and known as caspase-like in plants, due to their different sequence respect to mammalian counterpart (Cai et al., 2014; Chichkova et al., 2012; $\mathrm{Xu}$ and Zhang, 2009). The action of the active caspases on their substrates causes morphological changes leading to cell death (Kim et al., 2003). Considering that organisms belonging to different kingdoms present strong similarities in these processes, it was expected that also some regulators and executioners of animal apoptosis could be still conserved in plant PCD manifestation and signalling (Fomicheva et al., 2012). However, no animal caspase orthologues have been found in plant genomes and the plant proteases closest to animal caspases, the metacaspases, are unable to cleave synthetic caspase substrates (Salvesen et al., 2015). The plant caspase-like activities, therefore, originate from proteases structurally unrelated to animal caspases, although the identification of plant proteins responsible for proteolytic caspase-like activities is still in progress (Cai et al., 2014; Schaller, 2004).

Two major pathways for caspase activation have been so far defined in metazoans: the extrinsic death receptor pathway and the intrinsic or mitochondrial pathway (Kumar, 2007). The intrinsic pathway starts with the induction of assembly of the caspase- 9 activating complex, named proteasome. Upon proteasome activation, caspase- 9 can propagate a cascade of further caspase activation events by direct processing of effector caspases. Proteasome-involving machinery is one of the main protein degradation systems of eukaryotic cells that not only removes misfolded and defective proteins, but also controls various cellular pathways through the selective removal of short-lived regulatory proteins (Üstün et al., 2016).

In plants, proteasome (26S proteasome complex) is composed by 31 polypeptides, organized in two sub-complexes. The first is the ATP-and ubiquitin (Ub)-independent catalytic core particle, or $20 \mathrm{~S}$ proteasome (20SP), where proteins are degraded. The second complex is composed of two regulatory particles, or 19S proteasomes, which cap the 20SP and confer ATP dependence and Ub recognition (Sadanandom et al., 2012).

Recent studies evidenced a possible involvement of 20SP in plant developmental PCD, as shown in poplar where xylem development is dependent on a caspase-3-like activity associated to this proteasome component (Han et al., 2012). This finding supports the view that some aspects of the molecular machinery of PCD seem to be conserved between plants and animals (Kim et al., 2003). On the other hand, Hatsugai et al. (2009) demonstrated that caspase-3-like proteolytic activity in Arabidopsis could be attributable to $20 \mathrm{~S}$ proteasome beta A1 subunit (PBA1) also in bacteria-induced PCD. These authors showed that PBA1 mediated the fusion of plasma membrane to tonoplast, leading to vacuolar autophagy. In addition, proteasome inhibition seems to be involved in cell death pathway in Arabidopsis, since proteasome disruption leads to a PCD form that is characterized by ROS production and caspase-like activation (Kurepa and Smalle, 2008). Furthermore, UPS is required for defence priming and the proper establishment of systemic acquired resistance, by preventing futile defence activation (Matsushita et al., 2013; Spoel et al., 2009). In addition, bacterial effectors are able to interfere with plant proteasome, causing to inhibition of its activity and thus leading to the pathogenic status (Üstün et al., 2016).
On the other hand, the role of proteasome in inducing the degradation of misfolded proteins is believed to be the key point in cellular proteomic stability, the impairment of which could increase the engulfment of subcellular compartments and thus leading to PCD (Li et al., 2010).

Among the environmental stresses that plants could face, toxic heavy metals (HMs) have been demonstrated to be strong triggers of PCD (Hasan et al., 2017). Despite the huge production and dispersion of metal-based salts and nanomaterials into the environment, the role of polluting metals from anthropic origin, in relation to their phytotoxicity, has not yet been fully investigated. These metals include elements like silver, mercury, lead, arsenic, cadmium, titanium and zinc (Vishwakarma et al., 2017; Yu et al., 2011). In particular, silver is widely utilized as metal nanoparticles, either occurring in a large array of healthcare antimicrobial products and outdoor facades formulated products (Kaegi et al., 2010; Mueller and Nowack, 2008).

Metal ions at high concentrations, exceeding the limit in plant tissues of $5 \mathrm{ppm} \mathrm{As}^{3+}, 2 \mathrm{ppm} \mathrm{Cd}^{2+}, 18 \mathrm{ppm} \mathrm{Cr}^{6+}, 46 \mathrm{ppm} \mathrm{Cu}^{2+}, 3 \mathrm{ppm}$ $\mathrm{Pb}^{2+}, 200-1000$ ppm $\mathrm{Al}^{3+}, 0.1-10 \mathrm{ppm} \mathrm{Co}{ }^{2+}, 100 \mathrm{ppm} \mathrm{Mn}^{2+}, 4 \mathrm{ppm}$ $\mathrm{Ni}^{2+}$ and 160-300 ppm Zn ${ }^{2+}$, (Hajar et al., 2014; Yadav, 2010), could affect cellular protein homeostasis, modifying the biological functions of proteins by altering their native conformation, stimulating aggregation of nascent proteins, leading to endoplasmic reticulum modifications and decrease of cell viability, probably by interference with the UPS (Dametto et al., 2015; Hasan et al., 2017).

It is generally accepted that a marker of plant response to HMs stress is also represented by the modulation of Ub gene expression (Hasan et al., 2017). Moreover, recent studies showed the involvement of caspase-like activities, DNA fragmentation and mitochondrial dysfunctions during PCD events caused by different HMs (Dametto et al., 2015; Iakimova and Woltering, 2017; Karmous et al., 2014; Petrov et al., 2015).

Interestingly, in a study on the effects of environmental HM exposure on animal neurodegenerative disease development (Yu et al., 2011), the activation of protein turnover alteration was reported. Conservation of a common response to HM toxicity shared between animals and plants could be very suggestive.

The present work aimed at evaluating the PCD manifestation induced by silver in a simplified plant cell model. We also investigated the degradation of proteasome complex subunit in association to PCD when grapevine cell cultures were exposed to silver ion.

\section{Material and methods}

\subsection{Plant material and culture conditions}

Dark-grown grapevine (Vitis vinifera L., cv. Limberger) callus cultures were maintained as described in Bertolini et al. (2016).

For the assay experiments, $4 \mathrm{~g}$ (FW) of 24-D-old cultures was transferred into $100 \mathrm{~mL}$ of modified liquid Murashige-Skoog medium into $250 \mathrm{~m}$ L-flask. For silver treatment, different concentrations of $\mathrm{AgNO}_{3}$ (obtained from a $10 \mathrm{mM}$ aqueous stock solution and sterilized by $0.45 \mu \mathrm{m}$ syringe filter) were added to Grapevine Suspension cell Culture (GSC) at the time of transfer. The flasks were then incubated at $27 \pm 1{ }^{\circ} \mathrm{C}$ under a $12 \mathrm{~h}$-light period (fluorescent lamp, with light intensity of $10 \mathrm{klux}$ ), for $6,24,48$ or $72 \mathrm{~h}$ in an INNOVA 2300 platform shaker, rotating at $110 \mathrm{rpm}$. When PCD manifestation was assayed in the presence of $10 \mu \mathrm{M}$ of the caspase-3-like inhibitor DEVD-CHO (diluted from a $10 \mathrm{mM}$ stock solution in dimethyl sulfoxide), $0.4 \mathrm{~g}$ (FW) of cultures were incubated in $10 \mathrm{~mL}$ of liquid medium, into $25 \mathrm{~mL}$-flasks. The experiments were carried out at least in three independent replicates. 


\subsection{Determination of $P C D$}

At different sampling times, $0.5 \mathrm{~mL}$ aliquots of GSC (approx. $20 \mathrm{mg}$ FW) were incubated with $8 \mu \mathrm{g} / \mathrm{mL}$ fluorescein diacetate (FDA) for $5 \mathrm{~min}$ in the dark, and observed under LEICA Fluovert microscope (Bertolini et al., 2016). For each replicate, at least 100 cells were evaluated, and only FDA-stained green fluorescent cells were considered alive. The percentage of PCD was calculated as the ratio of dead cells undergoing cytoplasmic shrinkage, compared to the total cell number, as reported by Hogg et al. (2011).

\subsection{Determination of in vitro caspase-3-like activity}

At different sampling times, GSC were filtered by nylon gauze $(100 \mu \mathrm{m})$, immediately ground to powder with liquid nitrogen and stored at $-80^{\circ} \mathrm{C}$. The powder (approx. $3 \mathrm{~g} \mathrm{FW}$ ) was re-suspended in $3 \mathrm{~mL}$ of $20 \mathrm{mM}$ MOPS-KOH (pH 7.5), $1 \mathrm{mM}$ EDTA, $5 \mathrm{mM}$ 1,4-dithioerythritol (DTE) and $0.1 \%(\mathrm{w} / \mathrm{v})$ CHAPS, and incubated on ice for $30 \mathrm{~min}$. After centrifugation at $14,000 \mathrm{~g}$ for $30 \mathrm{~min}$ (Mikro $120 \mathrm{Het}-$ tich centrifuge), cytosolic proteins were concentrated by 10,000 MWCO concentrators (VIVASPIN 6, Sartorius, Göttingen, Germany) at $8000 \mathrm{~g}$ for $30 \mathrm{~min}$. Soluble proteins (approx. $10 \mu \mathrm{g}$ ) were used for the colorimetric assay of caspase-3-like activity in $100 \mathrm{mM}$ sodium acetate $(\mathrm{pH}$ 4.5), $0.1 \%(\mathrm{w} / \mathrm{v}$ ) CHAPS, with $25 \mu \mathrm{M}$ N-Acetyl-Asp-Glu-Val-Asp p-nitroanilide (Ac-DEVD-pNA, from a $10 \mathrm{mM}$ stock solution in dimethyl sulfoxide) as substrate. The absorbance at $405 \mathrm{~nm}$ was measured after $5 \mathrm{~h}$ of incubation at $32^{\circ} \mathrm{C}$, using a 96-well microplate in a final reaction volume of $200 \mu \mathrm{L}$ by Multilabel Plate reader (VICTOR ${ }^{3}$, Perkin Elmer, Waltham, USA).

\subsection{ROS determination}

ROS production was measured according to Bertolini et al. (2016), using $2^{\prime}, 7^{\prime}$-dichlorodihydrofluorescein diacetate $\left(\mathrm{H}_{2} \mathrm{DCFDA}\right)$ as a probe. Powder of GSC was extracted in $10 \mathrm{mM}$ Tris- $\mathrm{HCl} \mathrm{pH} 7.3$ with a ratio of $1: 1(\mathrm{w} / \mathrm{v})$, centrifuged at $14,000 \mathrm{~g}$ for $10 \mathrm{~min}$ and the supernatant, corresponding to $14 \mu \mathrm{g}$ protein, was incubated in 96-well microplate with $5 \mu \mathrm{M} \mathrm{H}_{2}$ DCFDA in a final reaction volume of $200 \mu \mathrm{L}$. The detection was performed after $2.5 \mathrm{~h}$ incubation in the dark, using a Multilabel Plate Reader (excitation and emission wavelength set at $485 \mathrm{~nm}$ and $535 \mathrm{~nm}$, respectively). Fluorescence A.U. (Arbitrary Units) were normalized by mg protein.

\subsection{Immuno-detection of PBA1 and of poly-ubiquitin conjugated protein (pUCP)}

GSC were obtained as above described for caspase-3-like activity assay. Soluble proteins $(15 \mu \mathrm{g})$ were separated under reducing conditions (10 mM 1,4-dithioerythritol, DTE) by $12 \%(\mathrm{w} / \mathrm{v})$ and $7.5 \%(\mathrm{w} / \mathrm{v})$ SDS-PAGE for detection of PBA1 and Ub, respectively, and electro-blotted onto nitrocellulose membrane. The blots were incubated at room temperature overnight with either a polyclonal antibody raised against PBA1 (anti-PBA1, 1/1000 dilution; Abcam, Italy), or with a polyclonal antibody raised against Ub (anti-UBQ11, 1/:10,000 dilution; AGRISERA, Sweden). The cross-reaction was detected by nitro blue tetrazolium and 5-bromo-4-chloro-3-indolyl phosphate staining, after incubation with alkaline phosphatase-conjugated anti-rabbit IgG antibody (1/2500 dilution; Sigma, St. Louis, MO, USA). Computer-assisted densitometric analysis of immunoblots was performed using Quantity One software (Bio-Rad, Hercules, USA).

\subsection{Determination of antioxidant metabolites}

For the detection of carotenoids, GSC were sampled at 0 and $24 \mathrm{~h}$, frozen in liquid nitrogen and ground with mortar and pestle to obtain powder. Fifty $\mathrm{mg}$ of powder was resuspended and homogenized in $0.5 \mathrm{~mL}$ of $90 \%(\mathrm{v} / \mathrm{v})$ acetone and $0.01 \mathrm{~N} \mathrm{NH}_{4} \mathrm{OH}$. Then $0.5 \mathrm{~mL}$ of $80 \%$ $(\mathrm{v} / \mathrm{v})$ acetone was added. The insoluble components were separated by centrifugation at $16,000 \mathrm{~g}$ (Sorvall rotor HB-4) for $10 \mathrm{~min}$. The supernatant was collected and used for the spectrophotometric analysis at $480 \mathrm{~nm}$ by a diode spectrophotometer 8453 (Agilent, Santa Clara, CA, USA). The carotenoid content was determined according to the method proposed by Wellburn (1994).

Flavonoid measurement was performed following the method described by Filippi et al. (2015). Briefly, GSC powder obtained as above described was resuspended in $400 \mu \mathrm{L}$ of cold methanol. DPBA (2-aminoethoxydiphenyl borate, $0.05 \%, \mathrm{w} / \mathrm{v}$, in ethanol) was added to samples with 1:2 ratio in a final reaction volume of $200 \mu \mathrm{L}$. The detection of fluorescence was performed after $2.5 \mathrm{~h}$ of incubation in the dark, using a Multilabel Plate reader (excitation and emission wavelength set at $465 \mathrm{~nm}$ and $535 \mathrm{~nm}$, respectively). The amount of flavonoids detected in GSC powder was expressed as equivalent of quercetin.

\subsection{Protein quantification}

The protein concentration assay was carried out according to the method of Bradford (1976), using bovine serum albumin as standard.

\subsection{Statistical data analysis}

Data were analysed as means of at least three independent replicates. The effects of different $\mathrm{AgNO}_{3}$ concentrations were analysed by using one-way ANOVA test, whereas the effects of incubation times (0, 6 or $24 \mathrm{~h}$ ), treatment $\left( \pm 10 \mu \mathrm{M} \mathrm{AgNO}{ }_{3}\right.$ or $\pm 10 \mu \mathrm{M}$ DEVD-CHO) and their interactions were compared by two-way ANOVA test. Treatment means were compared by Least Significant Difference (LSD) analysis, according to Fisher's statistical test, and different letters, assigned to means, indicate a statistical difference at $P \leq 0.05$. All statistical analyses were performed using the Statistica software ver. 10 (Statsoft Inc., Tulsa, OK, USA).

\section{Results}

\subsection{Characterization of grapevine callus cultures and GSC}

To identify the appropriate cultivation time for performing the experiments, we initially characterized the growth of callus cultures by measuring FW of cells sampled at 3-4 d-intervals up to $38 \mathrm{~d}$ (Additional file 1). The growth curve exhibited a typical sigmoidal trend, showing an initial lag-phase (0-11 d), followed by a logarithmic phase (11-35 d) and a final stationary phase (35-38 d). At $24 \mathrm{~d}$, callus clusters showed a high rate of cell division and high cell viability (approx. 70\%, result not shown). Therefore, callus cultures were transferred into liquid medium and grown under $12 \mathrm{~h}$-light photoperiod with shaking (110 rpm). GSC were preliminarily grown for a short period $(24,48$, or $72 \mathrm{~h}$ ), ensuring that cell viability would not be significantly affected by incubation conditions (not shown). 


\subsection{Effect of $\mathrm{AgNO}_{3}$ on GSC cell death}

After the transfer into liquid medium, GSC were used for investigating the effects of different $\mathrm{AgNO}_{3}$ concentrations and times of treatment on PCD induction. The effects of silver on GSC were evaluated after incubation with $0.1,1$, or $10 \mu \mathrm{M} \mathrm{AgNO}_{3}$ for 3 d. Living cells were evaluated by green fluorescence after FDA staining, while non-fluorescent cells, under visible light, showed either cytoplasm shrinkage (PCD) or swelling (necrosis), respectively (Fig. 1). Since the highest concentration of $\mathrm{AgNO}_{3}(10 \mu \mathrm{M})$ induced death in almost all cells after $24 \mathrm{~h}$, we decided to follow PCD time-course only within this period of incubation.

Fig. 2 shows that a significant level of PCD occurred after $24 \mathrm{~h}$ of incubation in $10 \mu \mathrm{M} \mathrm{AgNO}_{3}$-treated GSC, if compared to the level of control at $24 \mathrm{~h}$, increasing PCD up to $80 \%$. The overall effect of $\mathrm{Ag}^{+}$concentration on PCD was found to be highly significant $(p<0.001)$ (Ad-

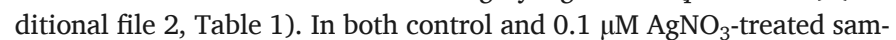
ples, a slight increase in PCD level was also detectable at $24 \mathrm{~h}$, although the difference with that observed at time 0 was not statistically significant. Most importantly, the characterization of time-course of PCD in GSC treated with $10 \mu \mathrm{M} \mathrm{AgNO}_{3}$ showed $40 \%$ of PCD already after $6 \mathrm{~h}$ of incubation (Fig. 2C).

Consistently, the percentage of necrotic cells did not change in treated-cells after $24 \mathrm{~h}$, even at the highest $\mathrm{Ag}^{+}$concentration, since necrosis remained near to basal level of approx. 20\% (Fig. 2B and D). The range of concentration of $\mathrm{Ag}^{+}$was thus sufficient to induce a program of cell dismantling, without provoking a massive leakage from cell membranes and swelling. As shown in Fig. 2D, the percentage of necrotic cells evaluated in control samples changed over time, being significantly decreased after $24 \mathrm{~h}$; similarly, ANOVA test confirmed that variance of time $\mathrm{x}$ concentration was significant $(p<0.05$; Additional file 2, Table 2).

\subsection{Effect of $\mathrm{AgNO}_{3}$ on $\mathrm{ROS}$ production}

The manifestation of PCD in plants is usually associated to oxidative burst, due to an increase of intracellular ROS generation (Petrov et al., 2015). In this regard, oxidative stress induced by $\mathrm{Ag}^{+}$on GSC was evaluated as increase of fluorescence due to $\mathrm{H}_{2}$ DCFDA complexation with ROS, after cleavage by cytosolic esterases. ROS production in GSC extracts exhibited a significant increase only in response to $10 \mu \mathrm{M} \mathrm{Ag}{ }^{+}$ (Fig. 3A), whereas lower concentrations of $\mathrm{Ag}^{+}(0.1$ and $1 \mu \mathrm{M})$ showed a slight, not significant, decrease when compared to untreated sample at $24 \mathrm{~h}$. Particularly, the effects of low $\mathrm{Ag}^{+}$concentrations on ROS production were overlapped by those due to complexation with ROS induced in liquid culture assessment. Treatment with $10 \mu \mathrm{M} \mathrm{AgNO}$ did not change ROS production (Fig. 3B and Additional file 2, Table 1) in GSC after $6 \mathrm{~h}$ of incubation, even if concomitantly the level of PCD was significantly increased (Fig. 2B).
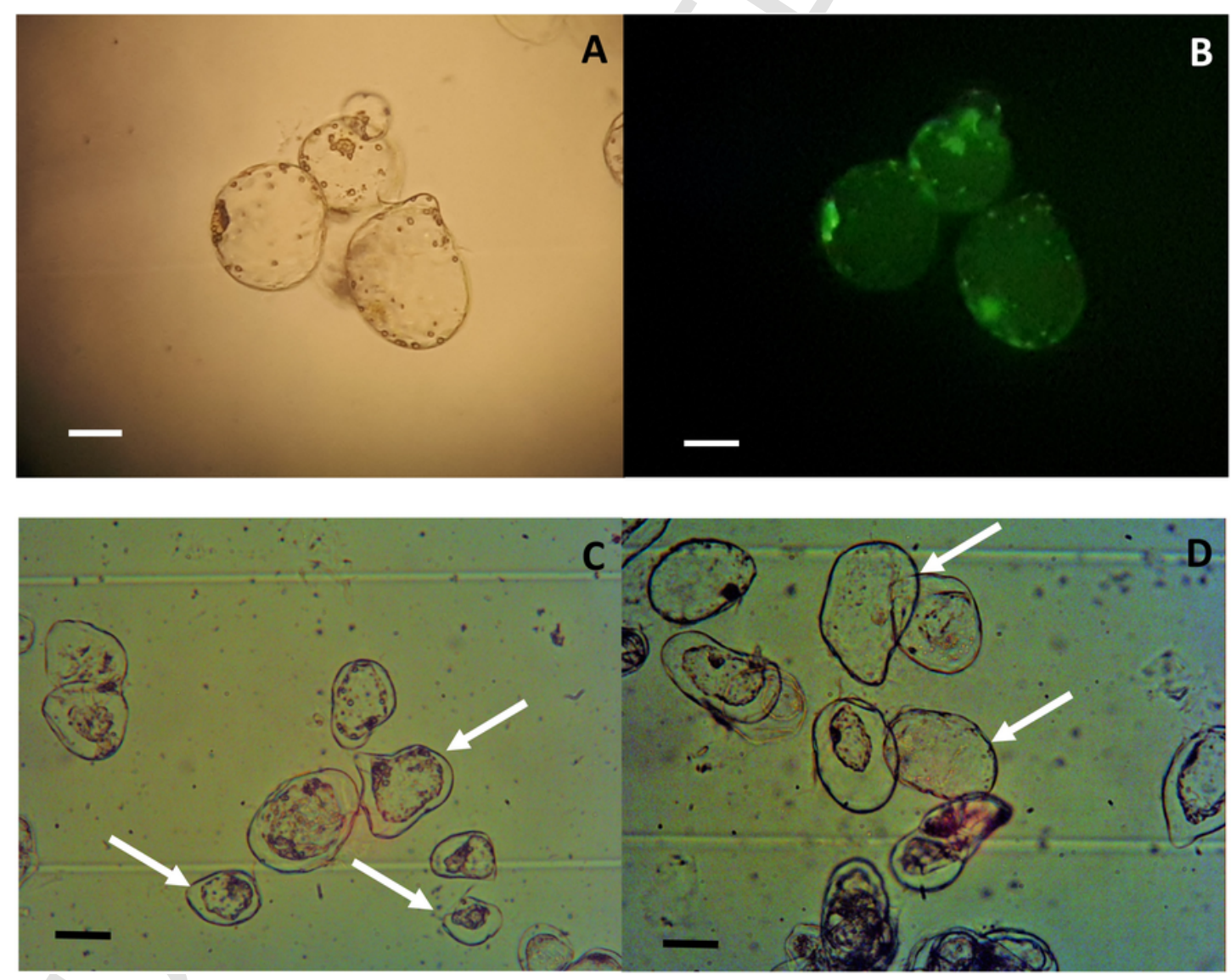

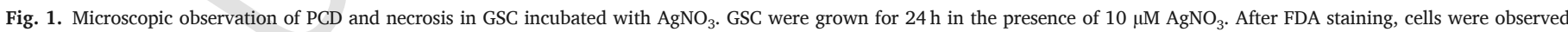

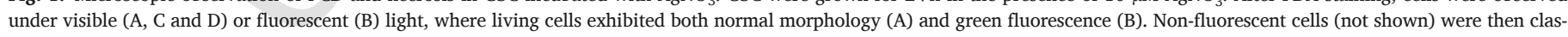


of the references to colour in this figure legend, the reader is referred to the web version of this article). 

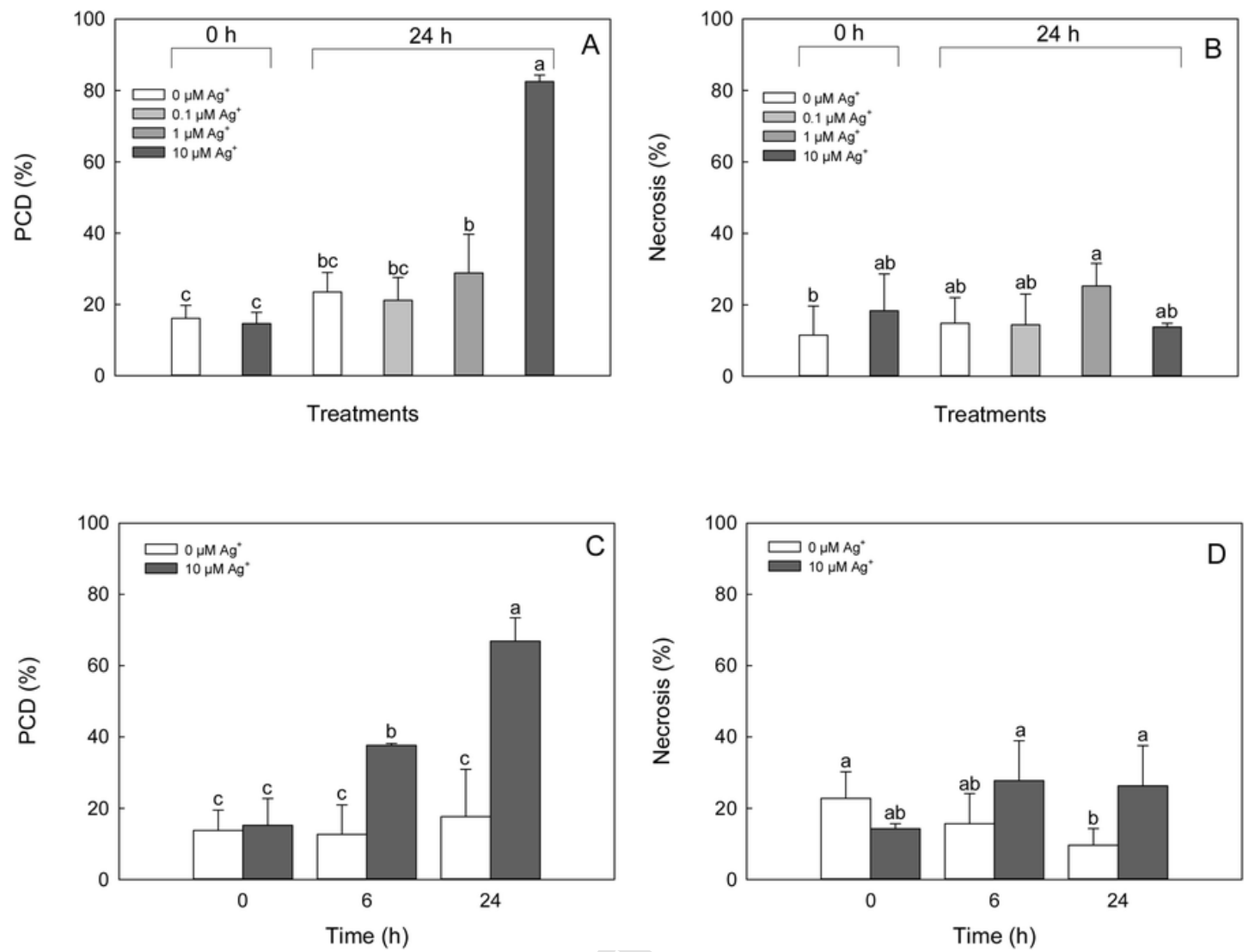



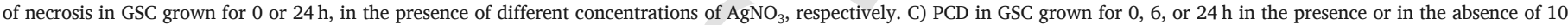

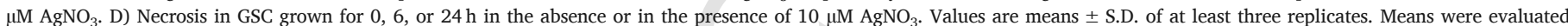

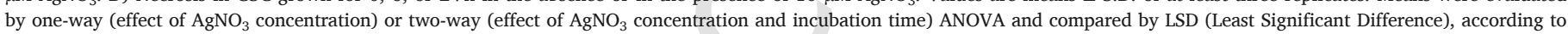
Fisher's statistical test. Different letters indicate a significant difference $(p \leq 0.05)$.

\subsection{DEVD-dependent caspase activity induced by $\mathrm{AgNO}_{3}$}

Since $10 \mu \mathrm{M} \mathrm{AgNO}_{3}$ induced PCD in GSC, we investigated if the process could involve the expression and activation of caspase-like proteases. Consistently, it has been demonstrated that caspase-3-like enzymes are directly involved in some developmental plant PCD processes (Ge et al., 2016; Han et al., 2012). Therefore, DEVD-dependent caspase-like activity was evaluated in GSC treated for $24 \mathrm{~h}$ with different concentrations of $\mathrm{AgNO}_{3}$ (Fig. 4). A basal level of caspase-3-like activity was already detectable in untreated GSC at both 0 and $24 \mathrm{~h}$, due to the presence in control samples of about 20\% PCD level. However, the caspase-3-like activity strongly increased after $24 \mathrm{~h}$ in GSC treated with $10 \mu \mathrm{M} \mathrm{AgNO}_{3}$ (Fig. 4A), when compared with the lower concentrations, showing a significant difference $(p<0.001$, additional file 2 , Table 1$)$. Furthermore, when the experiment was performed at $6 \mathrm{~h}$ (Fig. 4B), this activity was significantly affected by both incubation time and silver concentration, as well as their interaction (Additional file 2, Table 2).

The involvement of caspase-3-like enzymes in PCD induced by silver was further investigated by adding the caspase inhibitor (DEVD-CHO) to GSC. In samples treated for $24 \mathrm{~h}$ with $10 \mu \mathrm{M} \mathrm{AgNO}_{3}$ in the presence of the caspase inhibitor, PCD was significantly lowered from 80 to $60 \%$ (Fig. 4C and Additional file 2, Table 2, with $p<0.001$ ). It is noteworthy that DEVD-CHO did not significantly alter the percentage of necrotic cells in both treated and untreated samples at $24 \mathrm{~h}$ (Additional file 2, Table 1). In addition, DEVD-CHO strongly inhibited in vitro caspase-3-like activity in $\mathrm{Ag}^{+}$-treated GSC after $24 \mathrm{~h}$ (Fig. 4D), which is in agreement with the observed decrease in PCD. A slight effect of DEVD-CHO was also observed in the case of the basal caspase-like activity present in untreated cells (Fig. 4D).

\subsection{Accumulation of pUCP and degradation of PBA1 induced by $\mathrm{AgNO}_{3}$}

Since poly-ubiquitinated by-products are typically accumulated when proteasome system is disrupted or not functional, their detection represents a suitable diagnostic tool for cell metabolism impairment (Speranza et al., 2001). This analysis was, hence, performed in extracts obtained from GSC to verify if silver could also affect the function and the structure of proteasome system. The detection of pUCP, evaluated by immunoblotting, was used as a marker of proteasome system alteration (Fig. 5). In agreement with the above results, GSC incubated for $24 \mathrm{~h}$ with 1 and $10 \mu \mathrm{M} \mathrm{AgNO}{ }_{3}$ showed a significant increase in pUCP accumulation (Figs. 5A and 6A), as shown by a $p$ value < 0.001 in ANOVA for both concentration and time factors, as well as for their interaction $(p<0.01$ ) (Additional file 2, Table 2). These findings suggest that the proteasome-dependent proteolysis cascade was impaired during PCD induced by $\mathrm{Ag}^{+}$. Noteworthy, GSC treated with 1 $\mu \mathrm{M} \mathrm{AgNO}_{3}$ for $24 \mathrm{~h}$ showed a significant increase of pUCP accumulation (Figs. 5A and 6A). Interestingly, pUCP accumulation was indeed observed in both control and $10 \mu \mathrm{M} \mathrm{Ag}^{+}$-treated GSC after $6 \mathrm{~h}$. Then, poly- 

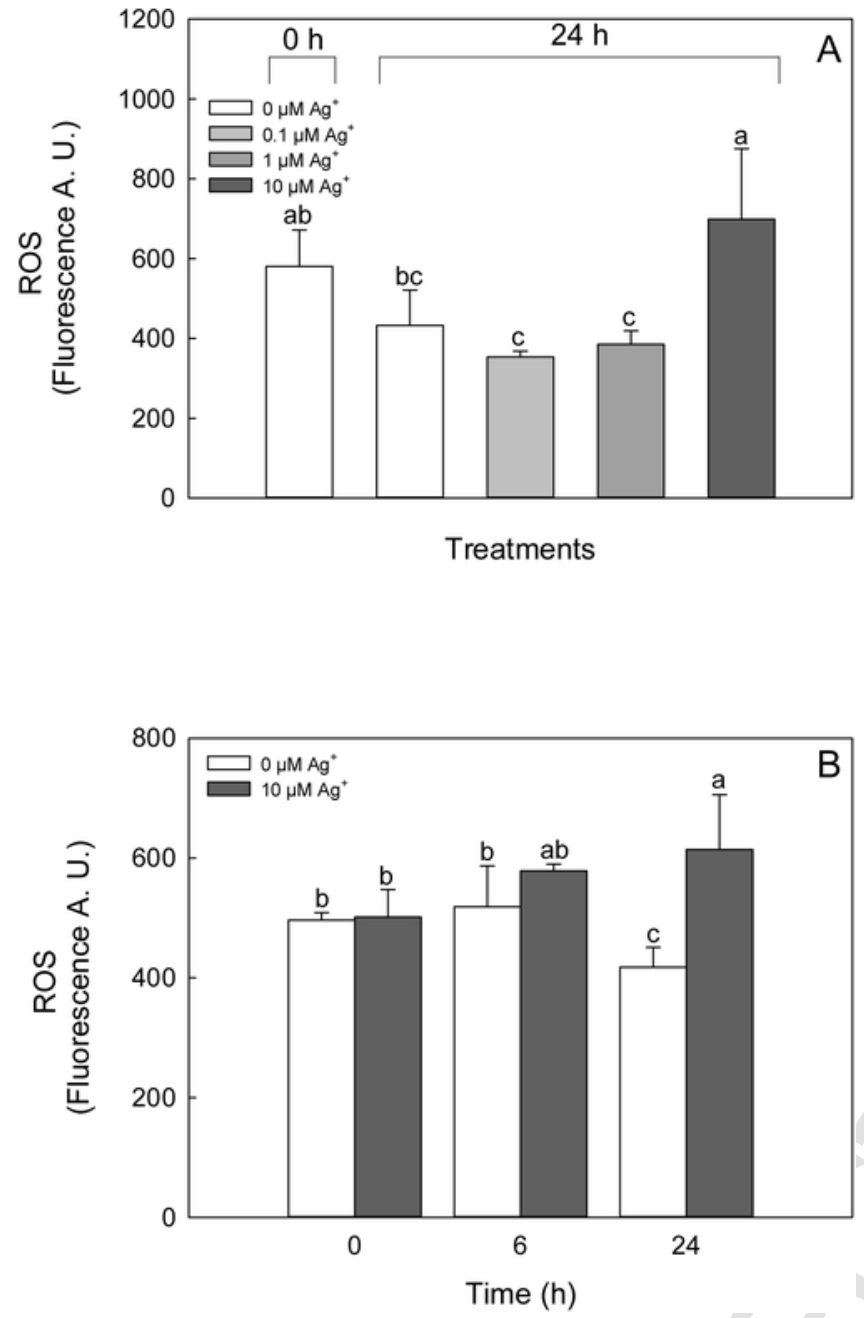

Fig. 3. Effect of $\mathrm{AgNO}_{3}$ on ROS production in GSC extracts. A) ROS production in GSC grown for 0 or $24 \mathrm{~h}$, in the presence of different concentrations of $\mathrm{AgNO}_{3}$, respectively. 3B) ROS formation in GSC grown for 0,6 or $24 \mathrm{~h}$ in the absence or presence of $10 \mu \mathrm{MAgNO}$. Values are means \pm S.D. of at least three replicates. Statistical analysis was the same as in Fig. 2.

ubiquitination significantly declined in untreated GSC from 6 to $24 \mathrm{~h}$, whereas it appeared significantly higher in $\mathrm{Ag}^{+}$-treated samples (Figs. $5 \mathrm{C}$ and $6 \mathrm{C}$ ).

The detection of PBA1 is considered a reliable marker of integrity of the proteasome, the complex responsible for recognition and cleavage of ubiquitinated proteins, since such a subunit is involved in the correct assembly of the 20SP complex in mammals (Hirano et al., 2008). Therefore, we used an anti-PBA1 antibody to quantify this component during $\mathrm{Ag}^{+}$-induced PCD in GSC (Figs. 5 and 6, Additional file 2, Tables 1 and 2). The results demonstrate that only when GSC were incubated for $24 \mathrm{~h}$ with $10 \mu \mathrm{M} \mathrm{AgNO}$ there was a significant decrease in PBA1 (Figs. $5 \mathrm{~B}$ and $6 \mathrm{~B}$ ), although the degradation was already initiated when GSC were incubated with $1 \mu \mathrm{M} \mathrm{AgNO}_{3}(p<0.001$, additional file 2, Table 2). PBA1 level did not change in GSC untreated or treated with $10 \mu \mathrm{M}$ $\mathrm{AgNO}_{3}$, analysed at $6 \mathrm{~h}$ (Figs. 5D and 6D).

\section{Discussion}

Recent advance about the use of metal nanomaterial in agro/medical and technological fields opens new questions regarding release of appreciable amounts of different metal ion species (e.g. Au, Ag or $\mathrm{Ti}$ ) in the environment (Vishwakarma et al., 2017; Yu et al.,
2011). Metal nanostructures are expected in the next future to be used in the agronomic field directly as plant nutrients or as shuttles for accurate delivery of nutrient or phytochemical to plant, as well as environmental remediation. For these reasons, it is conceivable that metals, usually present at low concentrations in nature, might raise at high level in soils in the next future. It is well-known that metal pollution impairs plant metabolism (Hasan et al., 2017), although phytotoxicity is strictly dependent on detoxification strategies, as well as on metal concentration, plant age and environmental source (Nagajyoti et al., 2010).

In this regard, our study aimed to determine the phytotoxicity of silver (in form of silver nitrate, $\mathrm{AgNO}_{3}$ ) in Vitis vinifera, as one of the most important crop plant. $\mathrm{Ag}^{+}$is not generally considered as pollutant in natural conditions, but it is largely used as nanomaterial in industrial processes (Kaegi et al., 2010) and may represent in the next future a significant part of nanomaterial waste. In our experimental plan, $\mathrm{Ag}^{+}$toxicity on Vitis vinifera cell cultures was evaluated at micromolar concentrations of nitrate salt $(0.1,1,10 \mu \mathrm{M}$, corresponding to 0.01 , $0.1,1 \mathrm{ppm}$, respectively), after incubation up to $24 \mathrm{~h}$. The application of $\mathrm{AgNO}_{3}$ to GSC was used utilized here as an in vitro bioassay test to investigate the possible direct interactions of $\mathrm{Ag}^{+}$with homogeneous, reproducible and undifferentiated cell system. Although several works report that $\mathrm{Ag}^{+}$and $\mathrm{Ag}$ nanoparticles inhibit root growth and alter their morphology, as well as they modify seed germination, these studies did not explore the possible effects of such metal on cell death (Pallavi et al., 2016; Yin et al., 2012). On the other hand, although PCD induced by HMs in plants has been already reported (Hasan et al., 2017), few works have dealt with $\mathrm{Ag}^{+}$induction of cell death (Vishwakarma et al., 2017), e.g. in mustard plant, where both ionic and nanoparticle forms of $\mathrm{Ag}^{+}$ cause DNA damage and PCD. In the present work, we verified that micromolar concentrations of $\mathrm{AgNO}_{3}(10 \mu \mathrm{M})$ induced approximately $80 \%$ of PCD after $24 \mathrm{~h}$ of treatment and we showed that PCD induction was positively correlated to $\mathrm{Ag}^{+}$concentrations and incubation time (Figs. 1 and 2). We suggest that the higher sensitivity to $\mathrm{Ag}^{+}$exhibited by GSC relies on the differences between our simplified system and the complex situation described in plants by Vishwakarma et al. (2017).

In plants, PCD manifestation is accompanied by formation of ROS, whether or not the latter represent the cause or the effect of PCD. ROS increase is considered as a signal linked to the induction of mitochondrial membrane permeability alteration, which not only decreases oxidative phosphorylation and ATP production, but also triggers the PCD process (Vianello et al., 2007). It is reported that $\mathrm{AgNO}_{3}$ induces accumulation of ROS and depletion of scavenger enzymes in plants (Vishwakarma et al., 2017). Accordingly, a strong increase of ROS in Ag-treated GSC was observed at $24 \mathrm{~h}$, if compared to control. On the contrary, in $\mathrm{AgNO}_{3}$-treated GSC with lowest concentrations (0.1 and $1 \mu \mathrm{M})$, ROS formation tend to decrease after $24 \mathrm{~h}$, in respect to the control $0 \mu \mathrm{M}$ at $24 \mathrm{~h}$. However, these lower concentrations significantly reduce ROS formation after $24 \mathrm{~h}$, if compared to control 0 $\mu \mathrm{M}$ at $0 \mathrm{~h}$. This effect could be explained by the activation of several signaling pathways involved in the re-enforcement of antioxidant system, described in both animals and plants, as reported by Jalmi et al. (2018). We also suggest that the decrease of ROS could depend on the activation of scavenger enzymes or on the synthesis of antioxidant molecules, induced by the transfer of cells from solid media into liquid growth medium, which implies a more metabolically active condition. Since only $10 \mu \mathrm{M} \mathrm{AgNO}$, was able to induce a significant ROS increase, we confirm that ROS and PCD are positively correlated to $\mathrm{Ag}^{+}$cytotoxicity after $24 \mathrm{~h}$ (Figs. $2 \mathrm{~A}$ and $3 \mathrm{~A}$ ). On the contrary, after $6 \mathrm{~h}$ incubation with $10 \mu \mathrm{M} \mathrm{AgNO}_{3}$ no difference in ROS production was observed (Fig. 3B), if compared to the control, where ROS 

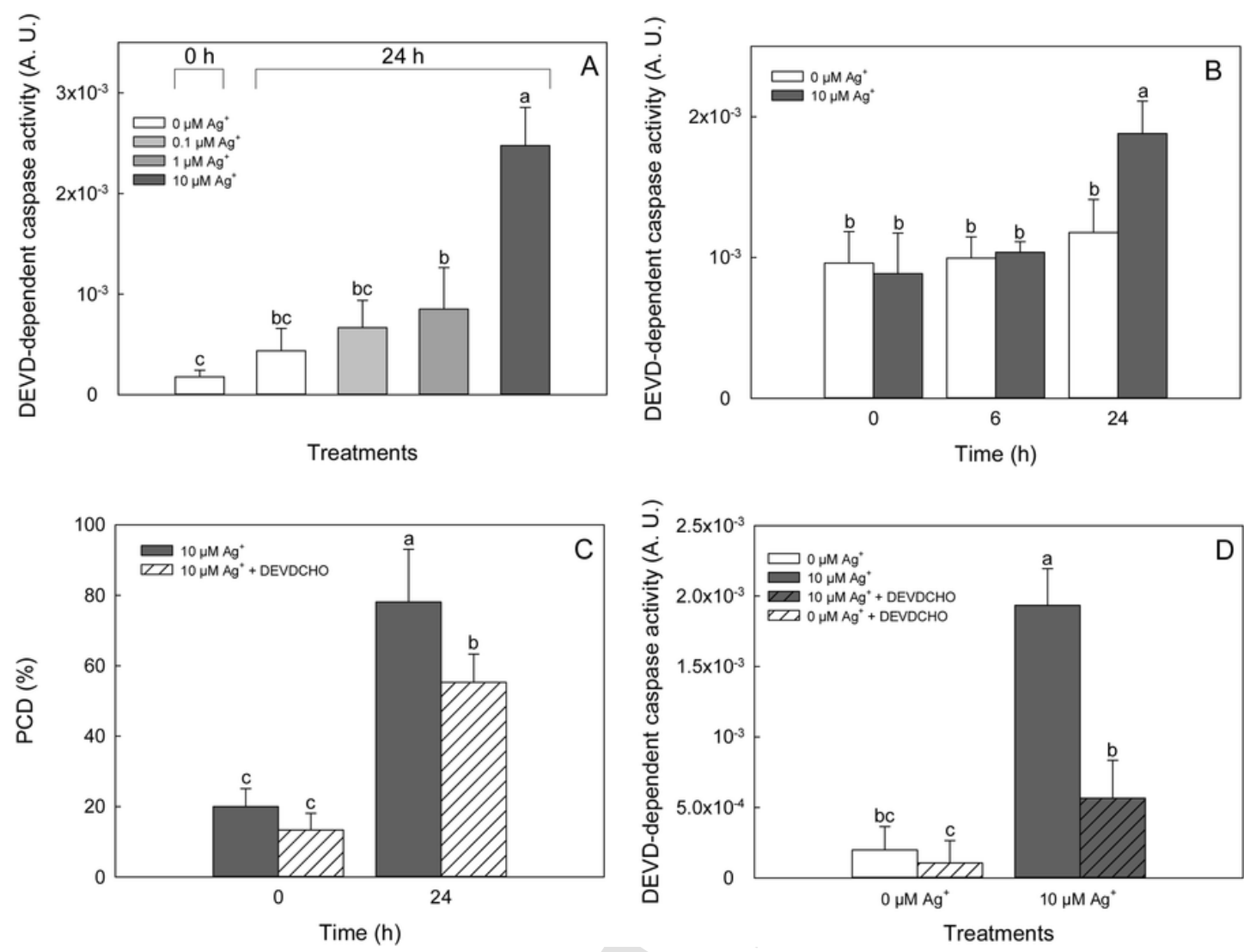



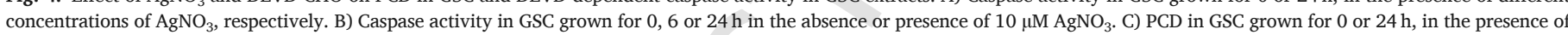

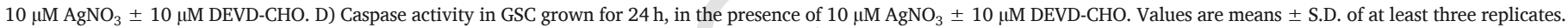
Statistical analysis was the same as in Fig. 2.

level even decreased after $24 \mathrm{~h}$. These data imply the induction of a transitory oxidative stress, probably due to different growth conditions and the presence of light, which the solid cell clumps faced when transferred from solid to liquid media. As demonstrated by Jiao et al. (2014), the supply of antioxidants to tobacco suspension cells reduces the rate of PCD induced by a fungal toxin and allows to restore the redox equilibrium during stress. This explanation could be applied also to our experimental conditions, as confirmed by the increase of antioxidant metabolites, such as carotenoids and flavonoids, in GSC samples after $24 \mathrm{~h}$, if compared to what observed at $0 \mathrm{~h}$ (Additional file 3, Tables 3 and 4). The correlation between PCD and cell redox status has been long debated in the last decade (Huang et al., 2014; Li and Xing, 2011; Van Breusegem and Dat, 2006) and, in most cases, the unbalance among antioxidants and ROS becomes a key regulator of PCD (Ge et al., 2016; Han et al., 2012).

In addition to cell shrinkage and DNA laddering, the expression of caspase-like enzymes is considered a suitable marker for detecting cells undergoing both developmental or stress-induced PCD (Ge et al., 2016; Han et al., 2012; Iakimova and Woltering, 2017; Xu and Zhang, 2009). In our system, we also found a strict relationship between PCD occurrence and DEVD-dependent caspase-3-like activity in GSC treated for $24 \mathrm{~h}$ with $10 \mu \mathrm{M}$ of $\mathrm{AgNO}_{3}$ (Fig. 4A). The DEVD-dependent activity was exerted by a caspase-like enzyme, as confirmed by its sensitivity to the specific inhibitor, when the activity was measured in vitro on cytosolic extracts from 24 h-treated cells (Fig. 4D). In addition, pre-incubation of GSC with the specific DEVD-caspase inhibitor resulted in the decrease of PCD induced by $10 \mu \mathrm{M} \mathrm{AgNO}$ (Fig. 4C). These findings confirmed that caspase-3-like activity was associated to $\mathrm{Ag}^{+}$-induced PCD in GSC, although the involvement of other caspase-like enzymes could not be excluded a priori. The time-course of DEVD-dependent caspase-3-like activity was similar to the pattern of PCD (cell shrinkage) manifestation and was consistently associated to $\mathrm{AgNO}_{3}$ concentration applied to GSC. This is, to the best of our knowledge, the first report of caspase-3-like involvement in plant PCD induced by $\mathrm{Ag}^{+}$.

The oxidative stress induced by $\mathrm{Ag}^{+}$may in turn also affect the UPS, similarly to what described in peanut root tips for $\mathrm{Al}^{3+}$, which is able to activate caspase-3 like enzymes (Huang et al., 2014). Accordingly, in bean cotyledons the copper-induced lipid peroxidation and hydrogen peroxide accumulation cause UPS impairment and lead to inactivation of proteasome activity, with accumulation of damaged proteins (Karmous et al., 2014). These results are partially in conflict with those obtained by Polge et al. (2009) in Arabidopsis, where $\mathrm{Cd}^{2+}$ induces 20SP synthesis, higher degradation of oxidized proteins and ultimately high resistance against $\mathrm{Cd}^{2+}$-induced oxidative stress. Indeed, the antioxidant protection observed in Arabidopsis involves mainly the $20 \mathrm{~S}$ sub-complex of the proteasome, which could act on proteins lacking the Ub tag. Instead, our attention was focused on the effect of pUCP, that are substrates for the complete $26 \mathrm{~S}$ form, including the 19S regulatory portion involved in the proteins de-ubiquitination process (Hirano et al., 2008). The latter form, as in the case of copper-induced stress (Karmous et al., 2014), appears to be more sensitive to oxidative conditions that led to its degradation (Kurepa et al., 2008; Kurepa and Smalle, 2008). On the other hand, a mild impairment of redox conditions favors the synthesis of $20 \mathrm{~S}$ form, leading to a more efficient removal of oxidized proteins thorough an Ub-independent mechanism (Reinheckel et al., 1998). In silver-treated GSC, ROS 

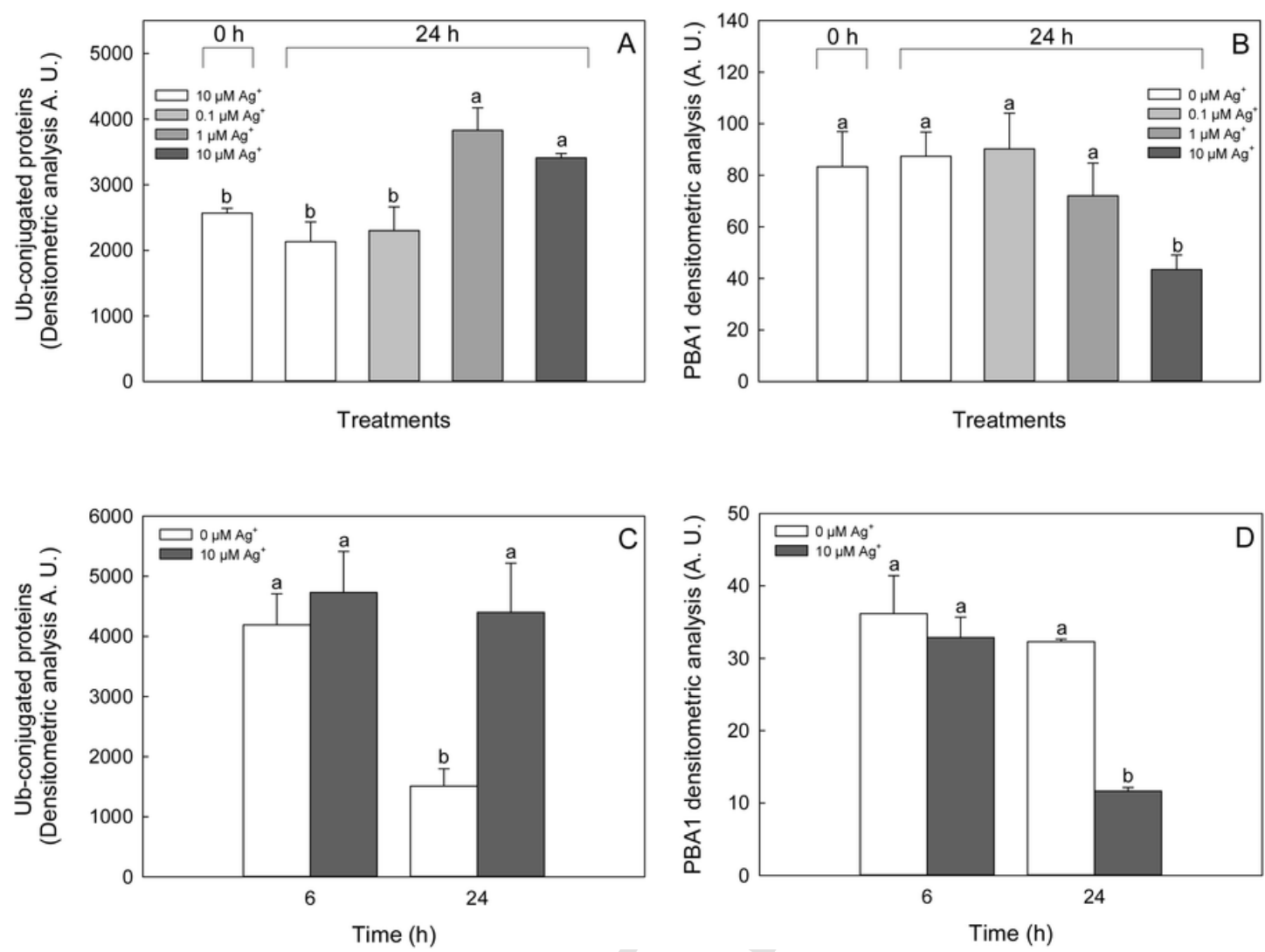

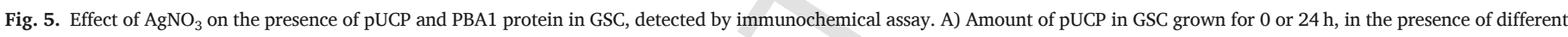

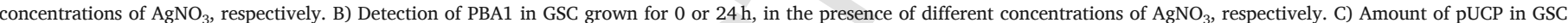

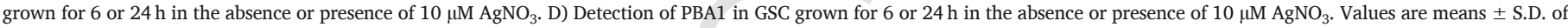
at least three replicates. Statistical analysis was the same as in Fig. 2.

did not seem to be the primary signal for UPS modulation. In fact, they are not a prerequisite, since the accumulation of pUCP, as a marker of UPS malfunctioning, has been already detected in the presence of $1 \mu \mathrm{M}$ $\mathrm{Ag}^{+}$after $24 \mathrm{~h}$ (Figs. 5A and $6 \mathrm{~A}$ ), while the same treatment did not induce a significant increase of ROS (Fig. 3A). It is reasonable to hypothesize that low $\mathrm{Ag}^{+}$concentration alone directly induced UPS malfunctioning, although PCD manifestation occurred together with oxidative stress and UPS degradation.

The accumulation pattern of pUCP in control and $\mathrm{Ag}^{+}$-treated GSC showed that a large accumulation of these intermediates took already place after $6 \mathrm{~h}$ in both control and treated samples (Figs. 5C and 6C). After $24 \mathrm{~h}$, the control samples reached a quite low level of pUCP, while stressed cells did not. We suggest that during transfer from solid to liquid medium, the cells were subjected to an oxidative and mechanical stress in the first hours, which could then be overcome only by untreated cells. On the contrary, in our experimental plan, 1 and 10 $\mu \mathrm{M} \mathrm{AgNO}{ }_{3}$ treatments induced an unbalance of the protection system that prevents UPS degradation and finally resulted in a large pUCP accumulation. The effects observed in GSC were similar to those described in animal fibroblasts cells, being HMs able to disrupt the complex Ub/proteasome, with consequent increase in cellular ubiquitinated protein concentration ( $\mathrm{Yu}$ et al., 2011). These authors evidenced that the alteration in basal regulation of UPS leads also to unbalance cellular antioxidant systems, by ROS hyper-accumulation and onset of protease enzymatic systems, such as caspase-3-like proteins. Indeed, 10 $\mu \mathrm{M} \mathrm{AgNO}_{3}$ induced the degradation of UPS in GSC, as confirmed by the decrease of PBA1 immunodetection (Figs. 5B and 6B). These data are in agreement with a progressive complete degradation of plant metabolic machinery due to proteolytic caspase-like activity, similarly to the animal model proposed by Yu et al. (2011). This observation may support, hence, the hypothesis that this mechanism could be well conserved also among different eukaryotic kingdoms. In both models, HMs exert their toxic effects by inducing protein turnover unbalance, together with PCD and proteolytic degradation. In the present work, we found that the decrease of PBA1, induced by high $\mathrm{Ag}^{+}$, affects the proteolytic activity of proteasome, as demonstrated by the increase of pUCP. On the other hand, this event did not cause an inhibition or decrement of the whole DEVD-dependent proteolytic activity, in contrast to what found in the characterization of PCD during xylem differentiation (Han et al., 2012). Indeed, it has to be considered that DEVD peptide, used for caspase-3-like activity assay in GSC, is actually a substrate for other isoforms of caspase-3-like, caspase-7-like and probably caspase-8-like enzymes (Bieri et al., 2016). These observations in a simplified model suggest that proteasome plays an essential function in PCD process also in plants.

\section{Conclusions}

Our results show that micromolar concentrations of $\mathrm{Ag}^{+}$induce the impairment of the UPS system activity and its disassembly, being the degradation of PBA1 a marker of the proteasome disruption in stressed GSC. As already stated by Üstün et al. (2016), the UPS, representing the main degradative protein machinery of the cell, is crucial to maintain a strictly regulated turnover of active proteins in order to respond adequately to several stresses, signals and stimuli. In this work, we showed immunochemical evidence supporting 


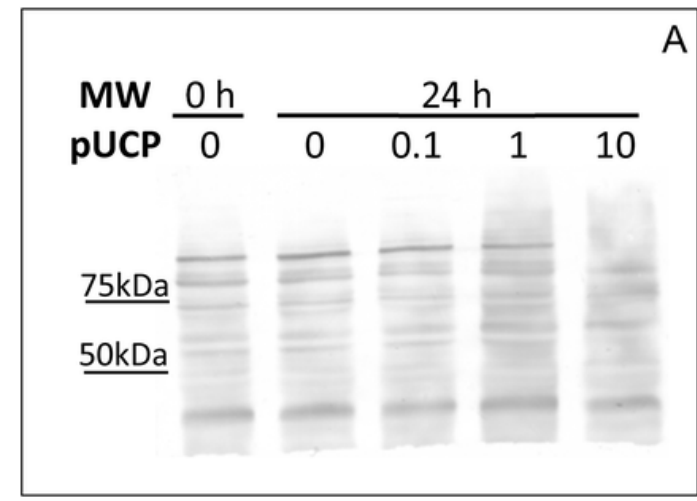

Treatment

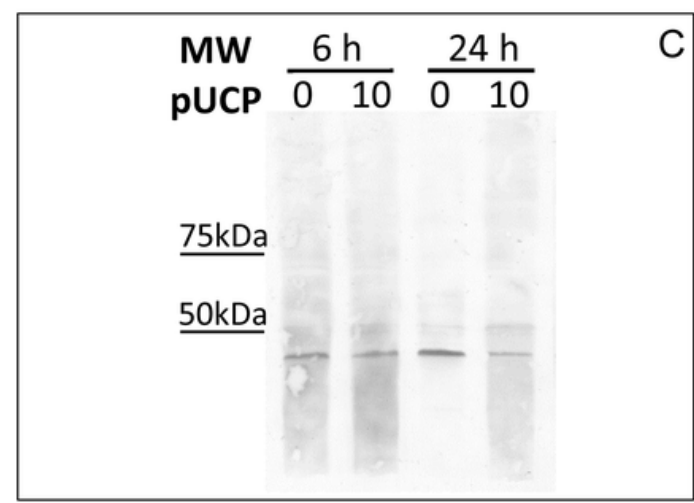

Treatment

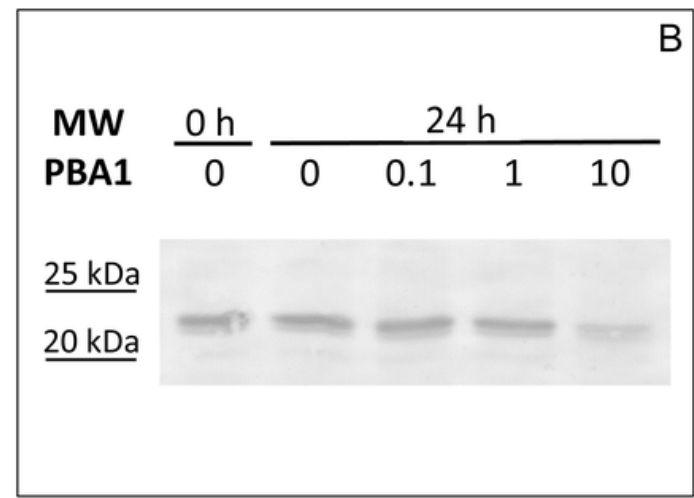

Treatment

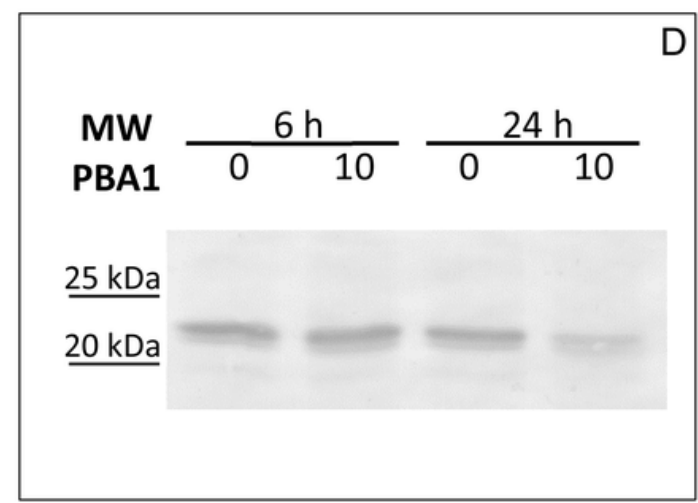

Treatment

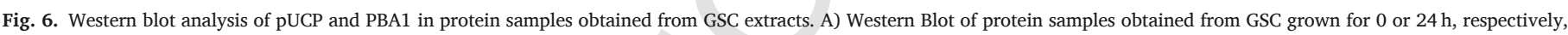

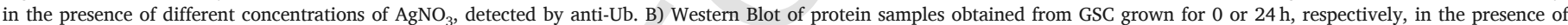

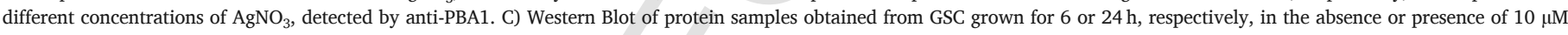


Protein molecular mass markers are shown on the left.

that also in plants UPS plays a relevant role as a regulator of PCD manifestation induced by silver contamination.

\section{Authors' contributions}

Antonio Filippi: Methodology, Data curation, Investigation, Writing-Original draft preparation.

Marco Zancani: Investigation, Writing-Original draft preparation, Reviewing and Editing.

Elisa Petrussa: Conceptualization, Supervision, Methodology, Data curation, Investigation, Validation, Writing-Original draft preparation, Reviewing and Editing. Enrico Braidot: Conceptualization, Supervision, Formal Analysis, Visualization, Writing-Original draft preparation, Reviewing and Editing, Project Administration.

All authors have read and approved the final version of the manuscript.

\section{Funding}

This research did not receive any specific grant from funding agencies in the public, commercial, or not-for-profit sectors.

\section{Declarations of interest}

None

\section{Acknowledgements}

We thank Dr. Vladimír Repka for providing the grapevine cell cultures, and Dr. Alberto Bertolini and Dr. Gabriele Bradamante for their contribution to some experiments.

\section{Appendix A. Supplementary data}

Supplementary material related to this article can be found, in the online version, at doi:https://doi.org/10.1016/j.jplph.2018.12.003.

\section{References}

Bertolini, A., Petrussa, E., Patui, S., Zancani, M., Peresson, C., Casolo, V., Vianello, A., Braidot, E., 2016. Flavonoids and darkness lower PCD in senescing Vitis vinifera suspension cell cultures. BMC Plant Biol. 16, 233. https://doi.org/10.1186/ s12870-016-0917-y.

Bieri, T., Onishi, M., Xiang, T., Grossman, A.R., Pringle, J.R., 2016. Relative contributions of various cellular mechanisms to loss of algae during cnidarian bleaching. PLOS One 11, https://doi.org/10.1371/journal.pone.0152693, e0152693. 
Borutaite, V., Brown, G.C., 2001. Caspases are reversibly inactivated by hydrogen peroxide. FEBS Lett. 500, 114-118.

Bradford, M.M., 1976. A rapid and sensitive method for the quantitation of microgram quantities of protein utilizing the principle of protein-dye binding. Anal. Biochem. 72, 248-254. https://doi.org/10.1016/0003-2697(76)90527-3.

Cai, Y.-M., Yu, J., Gallois, P., 2014. Endoplasmic reticulum stress-induced PCD and caspase-like activities involved. Front. Plant Sci. 5, https://doi.org/10.3389/fpls.2014. 00041.

Chichkova, N.V., Tuzhikov, A.I., Taliansky, M., Vartapetian, A.B., 2012. Plant phytaspases and animal caspases: structurally unrelated death proteases with a common role and specificity. Physiol. Plant. 145, 77-84. https://doi.org/10.1111/j.1399-3054. 2011.01560.x.

Dametto, A., Buffon, G., Blasi, É.A.D.R., Sperotto, R.A., 2015. Ubiquitination pathway as a target to develop abiotic stress tolerance in rice. Plant Signal. Behav. 10, https://doi. org/10.1080/15592324.2015.1057369, e1057369.

Filippi, A., Petrussa, E., Peresson, C., Bertolini, A., Vianello, A., Braidot, E., 2015. In vivo assay to monitor flavonoid uptake across plant cell membranes. FEBS Open Bio 5, 748-752. https://doi.org/10.1016/j.fob.2015.08.009.

Fomicheva, A.S., Tuzhikov, A.I., Beloshistov, R.E., Trusova, S.V., Galiullina, R.A., Mochalova, L.V., Chichkova, N.V., Vartapetian, A.B., 2012. Programmed cell death in plants. Biochem. Biokhimiia 77, 1452-1464. https://doi.org/10.1134/ S0006297912130044.

Fuentes-Prior, P., Salvesen, G.S., 2004. The protein structures that shape caspase activity, specificity, activation and inhibition. Biochem. J. 384, 201-232. https://doi.org/10. 1042/BJ20041142.

Ge, Y., Cai, Y.-M., Bonneau, L., Rotari, V., Danon, A., McKenzie, E.A., McLellan, H., Mach, L., Gallois, P., 2016. Inhibition of cathepsin B by caspase-3 inhibitors blocks programmed cell death in Arabidopsis. Cell Death Differ. 23, 1493-1501. https://doi.org/ 10.1038/cdd.2016.34

Hajar, E.W.I., Sulaiman, A.Z.B., Sakinah, A.M.M., 2014. Assessment of heavy metals tolerance in leaves, stems and flowers of Stevia Rebaudiana plant. Procedia Environ. Sci.. The 4th International Conference on Sustainable Future for Human Security SUSTAIN 2013 (20), 386-393. https://doi.org/10.1016/j.proenv.2014.03.049.

Han, J.-J., Lin, W., Oda, Y., Cui, K.-M., Fukuda, H., He, X.-Q., 2012. The proteasome is responsible for caspase-3-like activity during xylem development. Plant J. 72, 129-141. https://doi.org/10.1111/j.1365-313X.2012.05070.x.

Hasan, M.K., Cheng, Y., Kanwar, M.K., Chu, X.-Y., Ahammed, G.J., Qi, Z.-Y., 2017. Responses of plant proteins to heavy metal stress-a review. Front. Plant Sci. 8, https:// doi.org/10.3389/fpls.2017.01492.

Hatsugai, N., Iwasaki, S., Tamura, K., Kondo, M., Fuji, K., Ogasawara, K., Nishimura, M., Hara-Nishimura, I., 2009. A novel membrane fusion-mediated plant immunity against bacterial pathogens. Genes Dev. 23, 2496-2506. https://doi.org/10.1101/gad. 1825209.

Hirano, Y., Kaneko, T., Okamoto, K., Bai, M., Yashiroda, H., Furuyama, K., Kato, K., Tanaka, K., Murata, S., 2008. Dissecting $\beta$-ring assembly pathway of the mammalian $20 S$ proteasome. EMBO J. 27, 2204-2213. https://doi.org/10.1038/emboj.2008.148.

Hogg, B.V., Kacprzyk, J., Molony, E.M., O'Reilly, C., Gallagher, T.F., Gallois, P., McCabe, P.F., 2011. An in vivo root hair assay for determining rates of apoptotic-like programmed cell death in plants. Plant Methods 7, 45. https://doi.org/10.1186/ 1746-4811-7-45

Huang, W., Yang, X., Yao, S., LwinOo, T., He, H., Wang, A., Li, C., He, L., 2014. Reactive oxygen species burst induced by aluminum stress triggers mitochondria-dependent programmed cell death in peanut root tip cells. Plant Physiol. Biochem. 82, 76-84. https://doi.org/10.1016/j.plaphy.2014.03.037

Iakimova, E.T., Woltering, E.J., 2017. Xylogenesis in zinnia (Zinnia elegans) cell cultures: unravelling the regulatory steps in a complex developmental programmed cell death event. Planta 245, 681-705. https://doi.org/10.1007/s00425-017-2656-1.

Jalmi, S.K., Bhagat, P.K., Verma, D., Noryang, S., Tayyeba, S., Singh, K., Sharma, D., Sinha, A.K., 2018. Traversing the links between heavy metal stress and plant signaling. Front. Plant Sci. 9, 12. https://doi.org/10.3389/fpls.2018.00012.

Jiao, J., Sun, L., Zhou, B., Gao, Z., Hao, Y., Zhu, X., Liang, Y., 2014. Hydrogen peroxide production and mitochondrial dysfunction contribute to the fusaric acid-induced programmed cell death in tobacco cells. J. Plant Physiol. 171, 1197-1203. https://doi. org/10.1016/j.jplph.2014.03.015

Kaegi, R., Sinnet, B., Zuleeg, S., Hagendorfer, H., Mueller, E., Vonbank, R., Boller, M., Burkhardt, M., 2010. Release of silver nanoparticles from outdoor facades. Environ. Pollut. 158, 2900-2905. https://doi.org/10.1016/j.envpol.2010.06.009.

Karmous, I., Chaoui, A., Jaouani, K., Sheehan, D., El Ferjani, E., Scoccianti, V., Crinelli, R., 2014. Role of the ubiquitin-proteasome pathway and some peptidases during seed germination and copper stress in bean cotyledons. Plant Physiol. Biochem. PPB 76, 77-85. https://doi.org/10.1016/j.plaphy.2013.12.025.

Kim, M., Ahn, J.-W., Jin, U.-H., Choi, D., Paek, K.-H., Pai, H.-S., 2003. Activation of the programmed cell death pathway by inhibition of proteasome function in plants. J. Biol. Chem. 278, 19406-19415. https://doi.org/10.1074/jbc.M210539200.

Kumar, S., 2007. Caspase function in programmed cell death. Cell Death Differ. 14, 32-43. https://doi.org/10.1038/sj.cdd.4402060.
Kurepa, J., Smalle, J.A., 2008. Structure, function and regulation of plant proteasomes. Biochimie 90, 324-335. https://doi.org/10.1016/j.biochi.2007.07.019.

Kurepa, J., Toh-e, A., Smalle, J.A., 2008. 26S proteasome regulatory particle mutants have increased oxidative stress tolerance. Plant J. 53, 102-114. https://doi.org/10.1111/j. 1365-313X.2007.03322.x.

Li, Z., Xing, D., 2011. Mechanistic study of mitochondria-dependent programmed cell death induced by aluminium phytotoxicity using fluorescence techniques. J. Exp. Bot. 62, 331-343. https://doi.org/10.1093/jxb/erq279.

Li, D., Deng, Z., Chen, C., Xia, Z., Wu, M., He, P., Chen, S., 2010. Identification and characterization of genes associated with tapping panel dryness from Hevea brasiliensis latex using suppression subtractive hybridization. BMC Plant Biol. 10, 140. https://doi.org/ 10.1186/1471-2229-10-140.

Matsushita, A., Inoue, H., Goto, S., Nakayama, A., Sugano, S., Hayashi, N., Takatsuji, H., 2013. Nuclear ubiquitin proteasome degradation affects WRKY45 function in the rice defense program. Plant J. Cell Mol. Biol. 73, 302-313. https://doi.org/10.1111/tpj. 12035.

Mueller, N.C., Nowack, B., 2008. Exposure modeling of engineered nanoparticles in the environment. Environ. Sci. Technol. 42, 4447-4453.

Nagajyoti, P.C., Lee, K.D., Sreekanth, T.V.M., 2010. Heavy metals, occurrence and toxicity for plants: a review. Environ. Chem. Lett. 8, 199-216. https://doi.org/10.1007/ s10311-010-0297-8.

Pallavi, Mehta, C.M, Srivastava, R., Arora, S., Sharma, A.K., 2016. Impact assessment of silver nanoparticles on plant growth and soil bacterial diversity. 3 Biotech 6, 254 https://doi.org/10.1007/s13205-016-0567-7.

Petrov, V., Hille, J., Mueller-Roeber, B., Gechev, T.S., 2015. ROS-mediated abiotic stress-induced programmed cell death in plants. Front. Plant Sci. 6, https://doi.org/ 10.3389/fpls.2015.00069.

Polge, C., Jaquinod, M., Holzer, F., Bourguignon, J., Walling, L., Brouquisse, R., 2009. Evidence for the existence in Arabidopsis thaliana of the proteasome proteolytic pathway: Activation in response to cadmium. J. Biol. Chem. 284, 35412-35424. https:// doi.org/10.1074/jbc.M109.035394.

Reinheckel, T., Sitte, N., Ullrich, O., Kuckelkorn, U., Davies, K.J., Grune, T., 1998. Comparative resistance of the $20 \mathrm{~S}$ and $26 \mathrm{~S}$ proteasome to oxidative stress. Biochem. J. 335 637-642.

Sadanandom, A., Bailey, M., Ewan, R., Lee, J., Nelis, S., 2012. The ubiquitin-proteasome system: central modifier of plant signalling. New Phytol. 196, 13-28. https://doi.org/ 10.1111/j.1469-8137.2012.04266.x.

Salvesen, G.S., Hempel, A., Coll, N.S., 2015. Protease signaling in animal and plant-regulated cell death. FEBS J. 283, 2577-2598. https://doi.org/10.1111/febs.13616.

Schaller, A., 2004. A cut above the rest: the regulatory function of plant proteases. Planta 220, 183-197. https://doi.org/10.1007/s00425-004-1407-2.

Speranza, A., Scoccianti, V., Crinelli, R., Calzoni, G.L., Magnani, M., 2001. Inhibition of proteasome activity strongly affects Kiwifruit Pollen germination. Involvement of the ubiquitin/proteasome pathway as a major regulator. Plant Physiol. 126, 1150-1161. https://doi.org/10.1104/pp.126.3.1150.

Spoel, S.H., Mou, Z., Tada, Y., Spivey, N.W., Genschik, P., Dong, X., 2009. Proteasome-mediated turnover of the transcription coactivator NPR1 plays dual roles in regulating plant immunity. Cell 137, 860-872. https://doi.org/10.1016/j.cell.2009.03.038.

Üstün, S., Sheikh, A., Gimenez-Ibanez, S., Jones, A.M.E., Ntoukakis, V., Börnke, F., 2016. The proteasome acts as a hub for plant immunity and is targeted by Pseudomonas type-III effectors. Plant Physiol. 2016, pp.00808. https://doi.org/10.1104/pp.16. 00808.

Van Aken, O., Van Breusegem, F., 2015. Licensed to kill: mitochondria, chloroplasts, and cell death. Trends Plant Sci. 20, 754-766. https://doi.org/10.1016/j.tplants.2015.08. 002.

Van Breusegem, F., Dat, J.F., 2006. Reactive oxygen species in plant cell death. Plant Physiol. 141, 384-390. https://doi.org/10.1104/pp.106.078295.

Vartapetian, A.B., Tuzhikov, A.I., Chichkova, N.V., Taliansky, M., Wolpert, T.J., 2011. A plant alternative to animal caspases: subtilisin-like proteases. Cell Death Differ. 18 1289-1297. https://doi.org/10.1038/cdd.2011.49.

Vianello, A., Zancani, M., Peresson, C., Petrussa, E., Casolo, V., Krajňáková, J., Patui, S. Braidot, E., Macrì, F., 2007. Plant mitochondrial pathway leading to programmed cell death. Physiol. Plant. 129, 242-252. https://doi.org/10.1111/j.1399-3054.2006. 00767.x.

Vishwakarma, K., Shweta, null, Upadhyay, N., Singh, J., Liu, S., Singh, V.P., Prasad, S.M., Chauhan, D.K., Tripathi, D.K., Sharma, S., 2017. Differential phytotoxic impact of plant mediated silver nanoparticles (AgNPs) and silver nitrate $\left(\mathrm{AgNO}_{3}\right)$ on Brassica sp. Front. Plant Sci. 8, 1501. https://doi.org/10.3389/fpls.2017.01501.

Wellburn, A.R., 1994. The spectral determination of chlorophylls a and b, as well as tota carotenoids, using various solvents with spectrophotometers of different resolution. J. Plant Physiol. 144, 307-313. https://doi.org/10.1016/S0176-1617(11)81192-2.

Xu, C., Bailly-Maitre, B., Reed, J.C., 2005. Endoplasmic reticulum stress: cell life and death decisions. J. Clin. Invest. 115, 2656-2664. https://doi.org/10.1172/JCI26373.

Xu, Q., Zhang, L., 2009. Plant caspase-like proteases in plant programmed cell death. Plant Signal. Behav. 4, 902-904. 
Yadav, S.K., 2010. Heavy metals toxicity in plants: an overview on the role of glutathione and phytochelatins in heavy metal stress tolerance of plants. South Afr. J. Bot. 76, 167-179. https://doi.org/10.1016/j.sajb.2009.10.007.

Yin, L., Colman, B.P., McGill, B.M., Wright, J.P., Bernhardt, E.S., 2012. Effects of silver nanoparticle exposure on germination and early growth of eleven wetland plants. PLoS One 7, https://doi.org/10.1371/journal.pone.0047674, e47674.
Yu, X., Ponce, R.A., Faustman, E.M., 2011. Metals induced disruption of ubiquitin proteasome system, activation of stress signaling and apoptosis. Cellular Effects of Heavy Metals. Springer, Dordrecht, pp. 291-311. https://doi.org/10.1007/ 978-94-007-0428-2_14.

Zancani, M., Casolo, V., Petrussa, E., Peresson, C., Patui, S., Bertolini, A., De Col, V., Braidot, E., Boscutti, F., Vianello, A., 2015. The permeability transition in plant mitochondria: the missing link. Front. Plant Sci. 6, https://doi.org/10.3389/fpls.2015. 01120 . 